\title{
DEVELOPING A COMPETITIVE MODEL FOR HEALTH AND WELL-BEING TOURISM DESTINATIONS IN THAILAND: CONFIRMATORY FACTOR ANALYSIS APPROACH
}

\author{
Thadathibesra PHUTHONG* \\ Silpakorn University, Faculty of Management Science, Sam Phraya, Cha-am, Petchaburi, Thailand, e-mail: thadathibes@ms.su.ac.th
}

\begin{abstract}
Citation: Phuthong, T. (2021). DEVELOPING A COMPETITIVE MODEL FOR HEALTH AND WELL-BEING TOURISM DESTINATIONS IN THAILAND: CONFIRMATORY FACTOR ANALYSIS APPROACH. GeoJournal of Tourism and Geosites, 39(4spl), 1439-1449. https://doi.org/10.30892/gtg.394spl15-788
\end{abstract}

\begin{abstract}
This study assesses the consistency of the structural components of a model for developing a competitive health and well-being destination as viewed by health and well-being tourism entrepreneurs in an emerging Thai market. The sample consisted of 216 health and well-being tourism entrepreneurs recruited by purposive sampling. A questionnaire formatted using a five-point Likert scale was used. The questionnaire's Index of Item-Objective Congruence (IOC) varied from 0.60 to 1.00 , and its reliability ranged from 0.711 to 0.938 . Statistical analysis, frequencies, percentages, means, standard deviations, exploratory factor analysis and confirmatory factor analysis were utilised. The findings revealed the following seven model components: 1) health and well-being tourism resources and attractions, 2) infrastructure and facilities, 3) service design and development, 4) policy, planning and destination management, 5) knowledge management and learning organisation, 6) destination management and 7) innovative capacity. Governors, entrepreneurs, destination managers and stakeholders can use the discovered variables to evaluate a competitive health and well-being destination's expected performance, strengths, weaknesses and development opportunities. Further, this research should enable continuing support through the critical variable factors.
\end{abstract}

Key words: competitive model, health destination, well-being destination, health tourism, confirmatory factor analysis

$* * * * * * *$

\section{INTRODUCTION}

The COVID-19 pandemic has severely reduced tourism's worldwide value. The United Nations World Tourism Organization (UNWTO) evaluated COVID-19's impact on the tourism industry and found that the pandemic has costed approximately USD 1.3 trillion in income, resulting in 74\% decrease in international tourist visits from 2019 to 2020 (UNWTO, 2021). Clearly, the COVID-19 outbreak has affected tourism, with many people avoiding travel because of the perceived associated health risks (Gursoy and Chi, 2020; Chua et al., 2020). However, once the most critical phase of the COVID-19 pandemic passes, Thailand is expected to welcome tourists again. Health and wellness tourism will become a hot new trend, and entrepreneurs and stakeholders must prepare for a new era of tourism during which tourists place a higher premium on health and safety (National News Bureau of Thailand, 2020).

Health tourism refers to the combination of travel to tourist destinations with medical and health services, sports facilities, fitness centres and other health-promoting activities. Additionally, health tourism might be divided into two types: therapeutic tourism, which focuses on health rehabilitation; and health-promoting tourism, which focuses on illness prevention (Mueller and Kaufmann, 2001; Goodrich and Goodrich, 1987; Sheldon and Bushell, 2009). Thailand is a tourism destination known for its exceptional, beautiful and diverse natural and artificial destinations, traditions, culture and knowledge that are unique to each location. Thailand extensively uses its natural resources to preserve and restore health in various ways. The country's tourism industry also boasts experience and skills in service, traditional Thai massage, natural herbal spa services, various lodging structures and accessible transport infrastructure. Thailand takes excellent care of visitors and tourists, fully embodying its unique attitude of polite service. These qualities have positioned Thailand as Asia's health and wellness tourism leader and a worldwide health tourism destination. For example, Thailand ranked $17^{\text {th }}$ out of 46 global destinations ranked within the 2020-2021 Medical Tourism Index report on the Medical Tourism Association. Additionally, Thailand was ranked fifth in the medical tourism industry dimensions, and the global ranked $15^{\text {th }}$ in quality of facilities and services dimensions (Medical Tourism Association, 2020).

To take advantage of Thailand's strength in this area, the Ministry of Public Health's Department of Health Service Support developed a strategic plan to promote Thailand as an international health centre capable of competing with other wellness tourism destination countries globally. Furthermore, leveraging the strength of the nation's health care system to attract visitors seeking treatment can increase revenue and employment in local communities and across Thailand (Department of Health Service Support, Ministry of Public Health, 2016). Numerous countries adopted this approach to increase the competitiveness of their tourism destinations, which relies on the ability to develop attractive products and services in health and wellness tourism that incentivise more tourists to spend time and money in the area and create satisfaction and deliver impressive tourist experiences. Successfully competing for market share requires creating key performance metrics. A number of studies, such as research on the development and enhancement of Taiwan's health tourism destinations (Lee and $\mathrm{Li}, 2019$ ), the establishment of a competitiveness index for Iran's health tourism hotspots

\footnotetext{
* Corresponding author
} 
(Mosammam et al., 2019), a model of the variables influencing Nigerian medical tourism abroad (Eze et al., 2021), components of South Korea's medical tourism destinations' competitiveness (Junio et al., 2016), Singapore's competitive medical tourism destinations (Ganguli and Ebrahim, 2017), shaping the appeal of the health tourism attractions on the Spanish island of Gran Canaria (Medina-Muñoz and Medina-Muñoz, 2014), determinants affecting the deterioration of Russia's competitiveness as a medical tourism destination (Novikova et al., 2013), Serbia's worldwide tourist potential as a medical tourism destination (Snezana et al., 2013), the competitiveness factors affecting health tourism in an Alpine case study (Schalber and Peters, 2012), guidelines for the Egyptian medical tourism group's success and development (Helmy and Travers, 2009), and guidelines for gaining a competitive edge in the English-speaking Caribbean's medical tourism industry (Chambers and McIntosh, 2008) provide recent examples of such metrics.

A review of the research literature on developing models to enhance the competitiveness of health and well-being tourism destinations in the Thai context found a number of studies on enhancing the spatial and regional competitiveness of health and well-being tourism destinations. These studies include recommendations for increasing the competitiveness of Phuket's health tourism industry (Aksornpairoj, 2020), health tourism development in Nakhon Si Thammarat Province (Julatha, 2019), Nakhon Si Thammarat Province's health tourism growth to become the upper south's centre of health tourism (Akarawong et al., 2020), assessment of the suitability of hot springs in Krabi's Khlong Thom District for development as a role model of hot spring health tourism (Rattanadilok na Phuket and Weerakit, 2019) and recommendations for establishing health tourism management in hot springs across Thailand's northern area (Hongsub and Pookaiyaudom, 2015). Despite the number of studies found in the literature review, which are subsequently discussed, gaps were still found in the research. Consequently, the need exists for further study into methods to improve the competitiveness of Thailand's health and well-being tourist destinations on national and holistic levels.

This research aims to bridge this gap and examine, using empirical data, the components that affect the development of the competitiveness of health and well-being tourism destinations and the conformity of the structure of these components as perceived by health and well-being tourism entrepreneurs in Thailand. Government agencies, entrepreneurs, destination managers and stakeholders in health and well-being tourism destinations can benefit from these research findings, which provide a guide to improve competitiveness by identifying the strengths, weaknesses and opportunities for the development and enhancement of specific destinations and an investment strategy that considers the feasible opportunities.

\section{Research Hypothesis}

This study develops the hypothesis that the confirmatory factor model for developing a competitive health and wellbeing destination in Thailand is congruent and consistent with the empirical data.

\section{Methods}

The researcher gathered data from a literature review of research publications and academic articles on the development of competitiveness of health and well-being destinations. The research selection process selected articles published in English and Thai within five years. First, the following selection criteria were determined from the full-text document: content related to enhancing the competitiveness of health and well-being tourism destinations, research method quality met the criteria, no risk of bias, data contained complete results, appropriate research methodology, and appropriate human research ethical protection for personal data received in samples, by contributors, or from research participants.

The findings of the literature review indicated that the components and indicators for the development of competitiveness of health and well-being tourism destinations could be synthesised and used to develop a conceptual framework for preliminary research, as illustrated in Table 1 and Figure 1.

Table 1. Constructs and Indicators (Source: Author's data analysis 2021)

\begin{tabular}{|c|c|c|c|}
\hline Constructs & Code & Indicators & Sources \\
\hline \multirow{3}{*}{$\begin{array}{l}\text { Health and } \\
\text { Well-being } \\
\text { Tourism } \\
\text { Resources } \\
\text { and } \\
\text { Attractions }\end{array}$} & RES1 & nique and memorable identities & \multirow{3}{*}{$\begin{array}{l}\text { Armenski et al. (2018); Asmelash and Kumar (2019); Chen } \\
\text { (2020); Chen et al. (2016); Težak Damijanić (2019); Erbaş } \\
\text { and Perçin (2015); Goffi (2013); Hanafiah and Zulkifly } \\
\text { (2019); Liu et al. (2019); Lo et al. (2017); Mi et al. (2019) } \\
\text { Pan et al. (2019); Reitsamer and Sperdin (2016); Romão et } \\
\text { al. (2017); Suphachaimongkol et al. (2019); Szromek and } \\
\text { Naramski (2019); Tapak et al. (2019); Yan et al. (2017) }\end{array}$} \\
\hline & RES2 & $\begin{array}{l}\text { Tourism activities that can create a learning experience and } \\
\text { a lasting impression }\end{array}$ & \\
\hline & RES3 & $\begin{array}{l}\text { Tourism activities that engage with the local } \\
\text { as producing wellness and herbal products to } \\
\text { tourists }\end{array}$ & \\
\hline \multirow{4}{*}{$\begin{array}{l}\text { Infrastruc- } \\
\text { ture and } \\
\text { Facilities }\end{array}$} & INF1 & 's & \multirow{4}{*}{$\begin{array}{l}\text { Armenskiet al. (2018); Augustin et al. (2017); Dodescu and } \\
\text { Cohut (2016); Ege and Uslu (2018); Salinas Fernández et al. } \\
\text { (2020); Gajić et al. (2018); Gaman (2015); Hanafiah and } \\
\text { Zulkifly (2019); Li et al. (2016); Portolan(2019); Reisinger et } \\
\text { al. (2019); Reitsamer and Sperdin (2016); Roy et al. (2018); } \\
\text { Šajinović (2017); Tapak et al. (2019); Wang et al. (2020) }\end{array}$} \\
\hline & INF2 & ofor providing information & \\
\hline & INF3 & $\begin{array}{l}\text { services for activities, such as yoga, } \\
\text { s }\end{array}$ & \\
\hline & INF4 & Tourist facilities design that serves all types of clients & \\
\hline \multirow{3}{*}{$\begin{array}{l}\text { Service } \\
\text { Design and } \\
\text { Develop- } \\
\text { ment }\end{array}$} & SER1 & $\begin{array}{l}\text { Delivery of s؟ } \\
\text { knowledge an }\end{array}$ & \multirow{3}{*}{$\begin{array}{l}\text { Andrades and Dimanche (2019); Chen et al. (2016); } \\
\text { Erbaş and Perçin (2015); Gajić (2018); Garau and } \\
\text { Pavan (2018); Junio et al. (2016); Kelly et al. (2015); } \\
\text { Szromek and Naramski (2019); Tapak et al. (2019); } \\
\text { Yan et al. (2017) }\end{array}$} \\
\hline & SER2 & $\begin{array}{l}\text { Wellness promotion using natural methods such as herbal } \\
\text { baths, oil massage, hydrotherapy and others }\end{array}$ & \\
\hline & SER3 & $\begin{array}{l}\text { Making clients feel relaxed when using wellness promotion } \\
\text { services, such as décor that is in harmony with nature, } \\
\text { appropriate soothing music and others }\end{array}$ & \\
\hline
\end{tabular}




\begin{tabular}{|c|c|c|c|}
\hline & SER4 & $\begin{array}{l}\text { Service process that tracks problems or complaints within a } \\
\text { short period }\end{array}$ & \\
\hline & SER5 & $\begin{array}{l}\text { Continuous training to improve employees' or } \\
\text { practitioners' service quality }\end{array}$ & \\
\hline & SER6 & $\begin{array}{l}\text { Collaboration of employees or workers as a team in } \\
\text { response to client needs or complaints }\end{array}$ & \\
\hline \multirow{6}{*}{$\begin{array}{l}\text { Policy, } \\
\text { Planning } \\
\text { and } \\
\text { Destinati- } \\
\text { on } \\
\text { Manage- } \\
\text { ment }\end{array}$} & POL1 & $\begin{array}{l}\text { Focusing on consistent economic development that mostly } \\
\text { contributes to local community and environment }\end{array}$ & \multirow{6}{*}{$\begin{array}{l}\text { Añaña et al. (2018); Andrades and Dimanche (2019); } \\
\text { Erbaş and Perçin (2015); Asmelash and Kumar (2019); } \\
\text { Hanafiah and Zulkifly (2019); Kurek et al. (2020); } \\
\text { Reitsamer and Sperdin (2016); Suphachaimongkol et al. } \\
\text { (2019) }\end{array}$} \\
\hline & \begin{tabular}{|l|} 
POL2 \\
\end{tabular} & Laws, policies and measures supported by government agencies & \\
\hline & POL3 & Ability to assess risks to tourists using services/visiting & \\
\hline & POL4 & Concept presentation/delivering value to tourists & \\
\hline & POL5 & Brand development, destination experience, wellness tourism & \\
\hline & POL6 & Global standards recognised and accepted by tourists & \\
\hline \multirow{7}{*}{$\begin{array}{l}\text { Knowledge } \\
\text { Manageme } \\
\text { nt and } \\
\text { Learning } \\
\text { Organisa- } \\
\text { tion }\end{array}$} & KM1 & Knowledge transfer and consulting for business partners & \multirow{7}{*}{$\begin{array}{l}\text { Andrades and Dimanche (2019); Armenski et al. } \\
\text { (2018); Kelly et al. (2015); Suphachaimongkol et al. } \\
\text { (2019); }\end{array}$} \\
\hline & KM2 & $\begin{array}{l}\text { Assembling and storing knowledge to provide wellness } \\
\text { tourism services to tourists, nursing homes, researchers / } \\
\text { students and new entrepreneurs interested in starting a business }\end{array}$ & \\
\hline & KM3 & $\begin{array}{l}\text { Linking and applying knowledge to create new knowledge } \\
\text { or new services }\end{array}$ & \\
\hline & KM4 & $\begin{array}{l}\text { Having the necessary basic knowledge for e-commerce } \\
\text { businesses and using IT to gain competitive advantages }\end{array}$ & \\
\hline & KM5 & $\begin{array}{l}\text { Having the knowledge and adaptability to respond } \\
\text { promptly to the context of change }\end{array}$ & \\
\hline & KM6 & $\begin{array}{l}\text { Active learning to enhance the organisation's knowledge } \\
\text { and skills }\end{array}$ & \\
\hline & KM7 & $\begin{array}{l}\text { The ability to learn with people in diverse communities and } \\
\text { cultures }\end{array}$ & \\
\hline \multirow{9}{*}{$\begin{array}{l}\text { Destina- } \\
\text { tion } \\
\text { Manage- } \\
\text { ment }\end{array}$} & DM1 & Management of wellness promotion products & \multirow{9}{*}{$\begin{array}{l}\text { Añaña et al. (2018); Camisón et al. (2016); Hanafiah } \\
\text { and Zulkifly (2019); Liou et al. (2019); Mi et al. (2019); } \\
\text { Roy et al. (2018); Semenova et al. (2018); } \\
\text { Suphachaimongkol et al. (2019); Szromek and } \\
\text { Naramski (2019); Tapak et al. (2019); Meera and } \\
\text { Vinodan (2015) }\end{array}$} \\
\hline & DM2 & Management of processes and quality of services/products & \\
\hline & DM3 & Human resource management and development & \\
\hline & \begin{tabular}{|l|} 
DM4 \\
\end{tabular} & Financial and cost management & \\
\hline & \begin{tabular}{|l|} 
DM5 \\
\end{tabular} & Marketing management & \\
\hline & DM6 & Management to understand client needs & \\
\hline & \begin{tabular}{|l|} 
DM7 \\
\end{tabular} & Crisis Management & \\
\hline & DM8 & $\begin{array}{l}\text { Maintaining wellness tourism resources/environmental } \\
\text { sustainability and reducing waste in the organisation }\end{array}$ & \\
\hline & DM9 & Strategic management for wellness tourism & \\
\hline \multirow{6}{*}{$\begin{array}{l}\text { Innovation } \\
\text { Capacity }\end{array}$} & INN1 & $\begin{array}{l}\text { Application of electronic tourism systems and other } \\
\text { relevant service innovations }\end{array}$ & \multirow{6}{*}{$\begin{array}{l}\text { Bilbao-Terol et al. (2017); Dodescu and Cohut (2016); } \\
\text { Reisinger et al. (2019); Salinas Fernández et al. (2020); } \\
\text { Gajić et al. (2018); Hanafiah and Zulkifly (2019); } \\
\text { Romão et al. (2017) }\end{array}$} \\
\hline & INN2 & $\begin{array}{l}\text { Human capital for new services, such as personnel with } \\
\text { knowledge and expertise in wellness tourism, creativity and } \\
\text { passion for developing new products or services and others }\end{array}$ & \\
\hline & \begin{tabular}{|l|} 
INN3 \\
\end{tabular} & Open to service innovation & \\
\hline & INN4 & $\begin{array}{l}\text { Bringing local resources, knowledge and a unique local } \\
\text { identity to create strength of sale and add value to tourism } \\
\text { products and services }\end{array}$ & \\
\hline & INN5 & Continuous development of new work processes & \\
\hline & INN6 & $\begin{array}{l}\text { Always prepared; proposes new options instead of using } \\
\text { the same old methods to quickly solve problems }\end{array}$ & \\
\hline
\end{tabular}

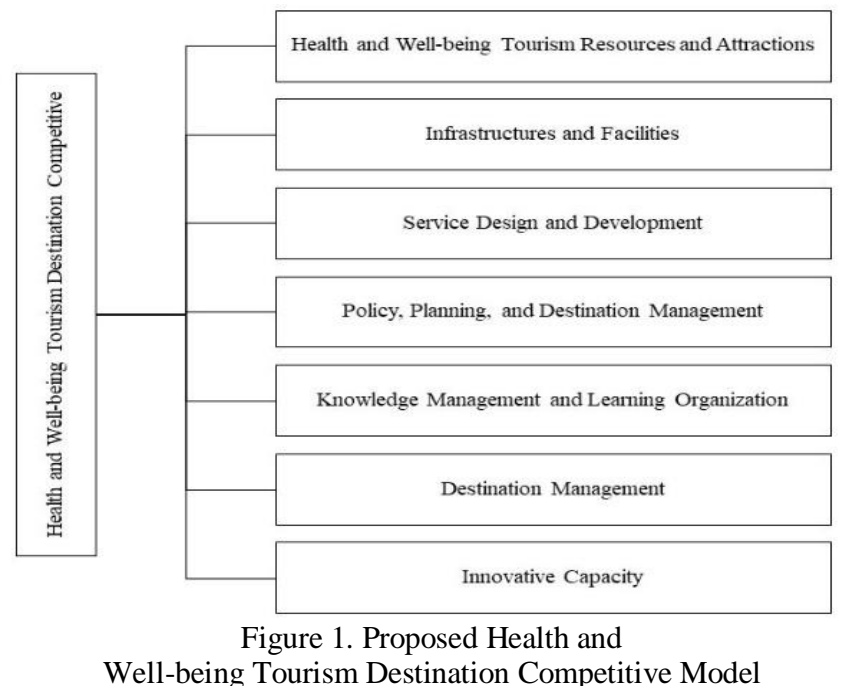

\section{Population and Sampling}

The population is the group of health tourism business operators collected during the data collection period. The Soper (2020) method for calculating the ratio of the sample unit to the number of parameters was used to randomly determine the sample size. The sample size calculation uses the structural equation model (SEM) based on the number of observable and latent variables for the effect size of the research, probability and required statistical power, as detailed as follows: Anticipated effect size $=0.3$

\section{Desired statistical power level $=0.8$}

Number of latent variables $=7$

Number of observed variables $=41$

Probability level $=0.05$

The calculation results indicate a recommended minimum of 180 samples. A non-probability sampling method was used with a specific sampling technique. 


\section{Survey Instrument}

The researcher used the survey research method. The tool used for data collection was a questionnaire that was divided into the following three parts:

Part 1 General information about the firms, four questions.

Part 2 General information about the respondents, five questions.

Part 3 Opinions about the importance of the following factors to enhance the competitiveness of health and well-being tourism destinations: 1) health and well-being tourism resources and attractions, three questions; 2) infrastructure and facilities, four questions; 3) service design and development, six questions; 4) policy, planning and destination management, six questions; 5) knowledge management and learning organisation, seven questions; 6) destination management, nine questions and 7) innovative capacity, six questions. Responses were provided using a five-level estimation Likert scale: not necessary, quite important, significant, very important and most important.

\section{Content Validity}

The researcher utilised the Item-Objective Congruence (IOC) index calculation technique by distributing the questionnaire to qualified individuals to ensure that the content was correct and the language expression was suitable. The five specialists represented the project evaluation, hospitality management, wellness tourism, spa business management and hotel and tourism management disciplines. As displayed in Table 2, no question had a conformance index score less than 0.50 (Rovinelli and Hambleton 1977), and the consistency index ranged between 0.60 and 1.00.

\section{Reliability Test}

The researcher pre-tested the questionnaire's reliability using a group similar to the sample group of 30 questionnaires, the Cronbach's alpha coefficient and a statistical package software. A confidence level of at least 0.7 demonstrated that the questionnaire was sufficiently trustworthy to infer acceptable confidence in all of the variables investigated (Hair et al., 2010). The Cronbach's alpha coefficients from 0.711 to 0.938 indicated that all questions met the requirements, as shown in Table 2 .

Table 2. Validity and Reliability Coefficient of Research Instrument (Pre-Test) (Source: Author's data analysis 2021)

\begin{tabular}{|l|c|c|c|c|}
\hline \multicolumn{1}{|c|}{ Construct } & No. of Items & IOC & Corrected Item-total Correlation & Cronbach's Alpha \\
\hline Health and Well-being Tourism Resources and Attractions & 3 & $0.60-1.00$ & $0.708-0.800$ & 0.711 \\
\hline Infrastructure and Facilities & 4 & $0.60-1.00$ & $0.749-0.921$ & 0.802 \\
\hline Service Design and Development & 6 & $0.80-1.00$ & $0.511-0.950$ & 0.888 \\
\hline Policy, Planning and Destination Management & 6 & $0.60-1.00$ & $0.691-0.975$ & 0.925 \\
\hline Knowledge Management and Learning Organisation & 7 & $0.80-1.00$ & $0.523-0.925$ & 0.909 \\
\hline Destination Management & 9 & $0.60-1.00$ & $0.590-0.926$ & 0.899 \\
\hline Innovative Capacity & 6 & $0.60-1.00$ & $0.717-0.978$ & 0.938 \\
\hline
\end{tabular}

\section{Data Collection}

The researcher administered both paper and online questionnaires by synchronising the survey data to Google Drive. A QR code and link were developed to facilitate the submission of an online questionnaire and the production of paper questionnaires. Three hundred questionnaires were also distributed to a group of Thai businesses engaged in health and well-being tourism from 1 November 2020, to 30 December 2020. Also included in each questionnaire was a reference letter, a call for collaboration to demonstrate the value of answering, data used to benefit others and ensuring the confidentiality of the answers received. In addition, to ensure the facility of the responses received, the researcher included a pre-addressed, stamped envelope to enable prompt return through the post. Participation in the study was optional and non-binding, and respondents could opt out by checking the box indicating their refusal to respond to the questionnaire.

If a sample agreed to participate in the study after having been informed of the rules for safeguarding individual rights, he or she simply ticked the consent box and proceeded to the next stage. In total, 235 questionnaires were received, 19 of which were incomplete, for 216 completed questionnaires-larger than the number of independent variables plus 50 (Harris, 2001) - indicating that the sample appropriately represents the population. The actual response rate was 78.33\%, higher than the allowed $20.00 \%$ for enterprise survey research through the post (Aaker et al., 2000). Additionally, research participants were primarily entrepreneurs or business owners, representing a good cross-section of the relevant population (Baruch and Holtom, 2008). An independent sample t-test was used to evaluate the data for non-response bias by comparing the completed initial and subsequent questionnaire responses. At the 0.05 significance level, the results indicated no statistically significant differences between the two groups' sample populations (Armstrong and Overton, 1977). The questionnaire response population was typical of the larger relevant population in this study.

\section{Data Analysis}

The researcher analysed both general information about the firms, such as their age, estimated annual revenue, establishment size (total number of employees) and the primary, types of services offered in the health and well-being tourism industry and respondents' data, such as gender, age, education level, current position and work experience in the health and well-being tourism industry. Then, using frequency, mean, percentage and standard deviation, exploratory and confirmatory factor analyses were performed to ensure the coherence of the structure-correlation model developed with empirical data. 


\section{RESULTS AND DISCUSSION}

\section{Demographic Information}

The sample group consisted of 216 firms. Classifying the data collected from the questionnaires by firm age revealed that half of the firms had been in existence for between five and ten years. Additionally, most earned more than one million baht per year or $50.0 \%$. Overall, the total number of employees is less than 50, accounting for $82.4 \%$ of total employment. Additionally, most health tourism companies provide activities and services, such as spas, Thai massages, fitness training, yoga, meditation, culinary classes and healthy food, accounting for $70.8 \%$ of total income.

The questionnaires were sent to a sample group of 216 persons. When categorised by gender, $66.7 \%$ were female. The majority, or $29.2 \%$, were between the ages of 26 and 45 . Those with a bachelor's degree accounted for $66.7 \%$ of all graduates. Furthermore, $66.7 \%$ were entrepreneurs or business owners. Additionally, the largest group of respondents, or $45.8 \%$ of the total, worked in the health tourism industry for six to ten years.

Moreover, according to an analysis of opinions on the importance of components in developing the competitiveness of health and well-being tourism destinations in seven dimensions, the destination management factor was identified as having the highest priority $(\overline{\mathrm{x}}=4.57, \mathrm{SD}=0.344)$, followed by service design and development $(\overline{\mathrm{x}}=4.55, \mathrm{SD}=0.431)$, innovative capacity $(\overline{\mathrm{x}}=4.57, \mathrm{SD}=0.344)$, health and well-being tourism resources and attractions $(\overline{\mathrm{x}}=4.22, \mathrm{SD}=0.637)$, policy, planning and destination management $(\overline{\mathrm{x}}=4.20, \mathrm{SD}=0.485)$, knowledge management and learning organisation $(\overline{\mathrm{x}}=4.14$, $\mathrm{SD}=0.562)$ and infrastructure and facilities $(\overline{\mathrm{x}}=4.13$, S.D. $=0.694)$. The standard deviation of all variables is less than 1.25 , suggesting that respondents demonstrated more consistent than divergent perspectives of the seven components of the competitiveness enhancement of health and well-being tourism destinations, as observed in Table 3.

Table 3. Respondent Perceptions of Competitive Health and Well-being Destination Dimensions (Source: Author's data analysis 2021)

\begin{tabular}{|c|l|c|c|}
\hline $\begin{array}{c}\text { Ran- } \\
\text { king }\end{array}$ & \multicolumn{1}{|c|}{$\begin{array}{c}\text { Competitive h ealth and } \\
\text { well-being destination dimensions }\end{array}$} & Mean & S.D. \\
\hline 1 & Destination management & 4.57 & 0.344 \\
\hline 2 & Service design and development & 4.55 & 0.435 \\
\hline 3 & Innovative capacity & 4.35 & 0.552 \\
\hline 4 & Health and well-being tourism resources and attractions & 4.22 & 0.637 \\
\hline 5 & Policy, planning and destination management & 4.20 & 0.485 \\
\hline 6 & Knowledge management and learning organisation & 4.14 & 0.562 \\
\hline 7 & Infrastructure and facilities & 4.13 & 0.694 \\
\hline \multicolumn{2}{|r|}{ Average mean score } & 4.31 & - \\
\hline
\end{tabular}

Table 4. Correlation Matrix of CFA Model Factors** $\mathrm{p}<0.01$ (Source: Author's data analysis 2021)

\begin{tabular}{|c|c|c|c|c|c|c|c|}
\hline & RES & INF & SER & POL & KM & DM & INN \\
\hline RES & 1 & & & & & & \\
\hline INF & $0.794^{* *}$ & 1 & & & & & \\
\hline SER & $0.560^{* *}$ & $0.660^{* *}$ & 1 & & & & \\
\hline POL & $0.608^{* * *}$ & $0.696^{* *}$ & $0.804^{* *}$ & 1 & & & \\
\hline KM & $0.543^{* *}$ & $0.613^{* *}$ & $0.795^{* *}$ & $0.828^{* *}$ & 1 & & \\
\hline DM & $0.397^{* *}$ & $0.497^{* *}$ & $0.680^{* *}$ & $0.584^{* *}$ & $0.725^{* *}$ & 1 & \\
\hline INN & $0.397^{* *}$ & $0.482^{* *}$ & $0.611^{* *}$ & $0.545^{* *}$ & $0.663^{* *}$ & $0.861^{* *}$ & 1 \\
\hline
\end{tabular}

\section{Exploratory Factor Analysis}

The Kaiser-Meyer-Olkin (KMO) sampling measure assay result was 0.937 . This value, which is close to 1 , indicates the suitability of the data used by the factor analysis technique. Additionally, Bartlett's test of sphericity revealed that the variables were substantially correlated (Chi-square $=6920.207, \mathrm{df}=820, \mathrm{p}$-value $<0.01$ ), suggesting the variables' correlation matrix was relative and, thus, acceptable for component analysis. The variables' relationships were then categorised using a factor analysis approach, and the number of components was reduced using principal component factor analysis with varimax rotation. This research employs criteria to determine the number of factors requiring an eigenvalue greater than 1 and a factor loading greater than 0.5 . The analytical findings are classified into the following seven distinct factor categories: 1) health and well-being tourism resources and attractions, 2) infrastructure and facilities, 3) service design and development, 4) policy, planning and destination management, 5) knowledge management and learning organisation, 6) destination management and 7) innovative capacity. Additionally, the reliability analysis determined that Cronbach's alpha coefficient was significantly higher than 0.7 , indicating that the questionnaire was sufficiently reliable (Hair et al., 2010). Each variable met the specified criteria with values ranging from 0.768 to 0.948 .

\section{Correlation Matrix}

Pearson's product moment correlation coefficient, which has a potential range of -1 to 1 , was carried out before the confirmatory factor analysis (CFA) to analyse the correlation between the component variables of the competitiveness development of health and well-being tourism destinations. The results are provided in Table 4 . Table 4 indicates that all variables were positively correlated $(\mathrm{p}<0.01)$, with values between 0.190 and 0.861 . When considering the suitability of multicollinearity, a correlation coefficient higher than 0.7 between one pair of variables might influence multicollinearity (Hair et al., 2010; Meyers et al., 2013). Therefore, independent testing was performed on these variables using KMO and Barlett's test of sphericity to determine the suitability of the variables. The KMO obtained was 0.761 , which is greater than 0.5. Additionally, Barlett's test of sphericity, which was statistically significant $(\chi 2=737.849, \mathrm{df}=21, \mathrm{Sig}=0.000)$, showed that these synthetic variants had no multicollinearity problems. Therefore, the sample is appropriate for further CFA (Hair et al., 2010).

\section{Confirmatory Factor Analysis}

The analysis model from the conformity test of the SEM for developing a competitive health and well-being destination based on the hypotheses and empirical data found that it was consistent with the empirical data given the harmony of the overall model fit. The statistical assessment of the model's degree of harmony with the empirical data found that the $\chi 2 / \mathrm{df}$ was 1.007, which passes the specified criterion of being less than 5. Furthermore, consideration of the group indices 
defined at a level greater than or equal to 0.90 found that all indices - TLI $=0.991$ and CFI $=0.993-$ met the specified criterion. Regarding the group indices defined at a level of less than 0.08, all indices, such as RMR $=0.030$, RMSEA $=$ 0.021 , GFI $=0.860$ and AGFI $=0.791$, were found to pass this criterion. Therefore, the research hypothesis that states the confirmatory factor model for developing a competitive health and well-being destination in Thailand is accepted as being congruent and consistent with the empirical data, as shown in Table 5. The results of the CFA are provided in Figure 2.

Table 5. Indicators of Fit for Measurement Model / Comparison of Measurement Model Fitness Indices Notes: CFI = comparative fit index; IFI = incremental fit index; TLI = Tucker Lewis index; RMSEA = root mean square error of approximation; $\mathrm{CMIN} / \mathrm{DF}=$ Chi-square/degrees of freedom

\begin{tabular}{|l|c|c|c|l|}
\hline Measure & $\begin{array}{c}\text { Level of } \\
\text { Acceptance }\end{array}$ & $\begin{array}{c}\text { First } \\
\text { Measurement } \\
\text { Model }\end{array}$ & $\begin{array}{c}\text { Final } \\
\text { Measurement } \\
\text { Model }\end{array}$ & Result \\
\hline CFI & $\begin{array}{c}\text { CFI > 0.90 (Hu } \\
\text { and Bentler, 1999) }\end{array}$ & 0.807 & 0.993 & Accept \\
\hline IFI & $\begin{array}{c}\text { IFI }>0.90(\text { Byrne, } \\
\text { 2001) }\end{array}$ & 0.809 & 0.994 & Accept \\
\hline TLI & $\begin{array}{c}\text { TLI }>0.90 \\
\text { Byrne, 2001) }\end{array}$ & 0.791 & 0.991 & Accept \\
\hline RMSEA & $\begin{array}{c}\text { RMSEA < 0.08 } \\
\text { (Hair et al., 2006) }\end{array}$ & 0.101 & 0.021 & Accept \\
\hline CMIN/DF & $\begin{array}{c}\mathrm{X}^{2} / \mathrm{df}<5.00(\text { Loo } \\
\text { and Thorpe, 2000) }\end{array}$ & 2.718 & 1.077 & Accept \\
\hline
\end{tabular}

When the construct validity for a measurement model variables is considered, for it to be found reliable, it should have a composite reliability of 0.70 or higher, a reliability that includes convergent validity based on average variance extracted (AVE) of 0.50 or higher and discriminant validity based on maximum shared value (MSV) (Hair et al., 2010). The confidence and reliability of the measurement model used in this study were determined to meet the requirements, as shown in Table 6.

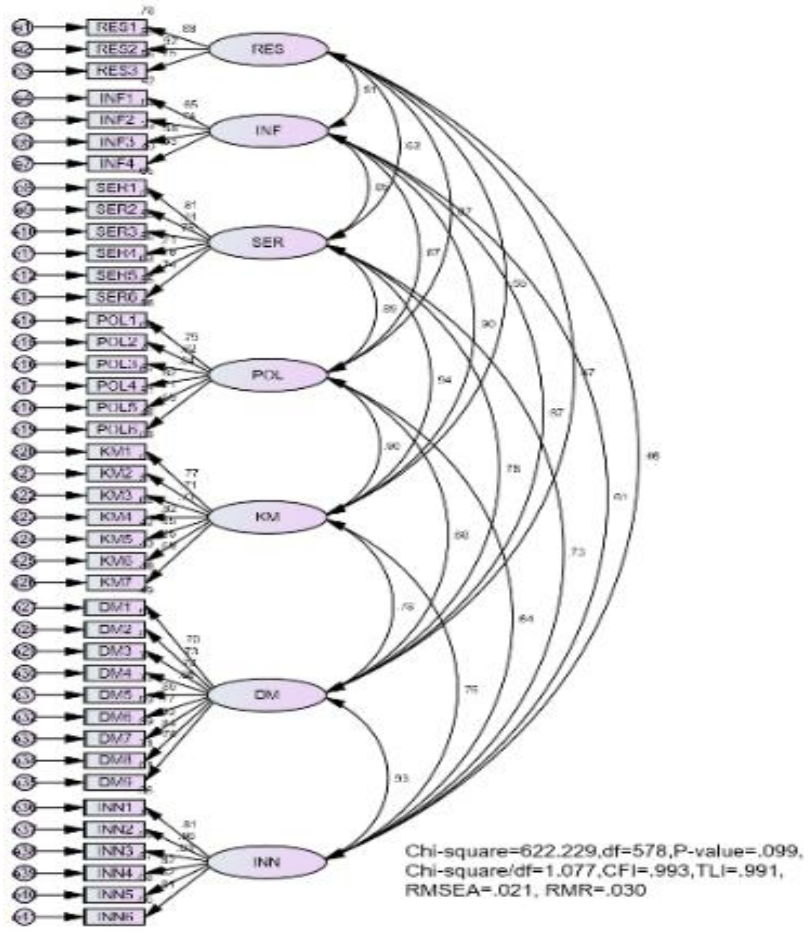

Figure 2. Measurement model (Source: Author's data analysis 2021)

Table 6. Construct Validity of First-order CFA Results (Source: Author's data analysis 2021)

\begin{tabular}{|c|c|c|c|c|c|c|}
\hline Construct & Items & $\begin{array}{c}\text { Factor } \\
\text { Loading }\end{array}$ & $\begin{array}{c}\text { Construct } \\
\text { Reliability (CR) }\end{array}$ & $\begin{array}{c}\text { Average Variance } \\
\text { Extracted (AVE) }\end{array}$ & $\begin{array}{c}\text { Maximum Shared } \\
\text { Variance (MSV) }\end{array}$ & $\begin{array}{c}\text { Average Shared } \\
\text { Variance (ASV) }\end{array}$ \\
\hline RES & RES1- RES3 & $0.747-0.924$ & 0.948 & 0.730 & 0.689 & 0.277 \\
\hline INF & INF1- INF4 & $0.578-0.735$ & 0.861 & 0.523 & 0.445 & 0.167 \\
\hline SER & SER1-SER6 & $0.708-0.806$ & 0.948 & 0.573 & 0.530 & 0.121 \\
\hline POL & POL1-POL6 & $0.695-0.843$ & 0.945 & 0.601 & 0.445 & 0.111 \\
\hline KM & KM1-KM7 & $0.652-0.824$ & 0.946 & 0.515 & 0.469 & 0.098 \\
\hline DM & DM1-DM9 & $0.703-0.858$ & 0.979 & 0.634 & 0.618 & 0.087 \\
\hline INN & INN1-INN6 & $0.809-0.860$ & 0.969 & 0.682 & 0.648 & 0.134 \\
\hline
\end{tabular}

\section{CONCLUSION}

CFA reveals that the competitiveness development component of health and well-being tourist destinations is composed of the following seven components comprising 41 indicators.

1. Health and well-being tourism resources and attractions are comprised of three indicators: i) unique and memorable identities, ii) health and well-being tourism activities that can create a learning experience and lasting impression and iii) health and well-being tourism activities that involve engagement with local people, such as producing wellness and herbal products for sale to tourists.

2. Infrastructure and facilities are comprised of four indicators: i) transport network that conveniently connects a tourist's residence to the destination, ii) infrastructure for providing information to tourists, iii) health and well-being tourism promotion services, such as yoga, exercise and aerobics and iv) design of tourist facilities that accommodate all types of clients.

3. Service design and development are comprised of six indicators: i) delivery of services to promote health and well-being tourism with knowledge and expertise, ii) promotion of health and well-being tourism using natural methods, such as herbal baths, oil massages and hydrotherapy, iii) making clients feel relaxed when using health and well-being tourism promotion services through methods that are in harmony with nature, such as décor and appropriate soothing music, iv) service processes designed to track and resolve problems or complaints within a short period, v) continuous training to improve the quality of service provided by employees or practitioners and vi) collaboration among employees or workers in response to client needs or complaints.

4. Policy, planning and destination management are comprised of six indicators: i) focus on consistent economic development that positively contributes to the local community and environment, ii) laws, policies and measures 
supported by government agencies, iii) ability to assess risks to tourists using services/visiting, iv) concept presentation or delivery of value to tourists, v) brand development, destination experience, health and well-being tourism and vi) global standards that tourists recognise and accept.

5. Knowledge management and learning organisation are comprised of seven indicators: i) knowledge transfer and consulting with business partners, ii) assembling and storing knowledge to provide wellness tourism services to tourists, nursing homes, researchers/students and new entrepreneurs and who are interested in starting a business, iii) linking and applying knowledge to create new knowledge or new services, iv) having the necessary basic knowledge for ecommerce businesses and using IT to gain competitive advantages, v) having knowledge and adaptability to respond promptly to the context of change, vi) active learning to enhance the knowledge and skills of the organisation and vii) the ability to learn with people in diverse communities and cultures.

6. Destination management is comprised of nine indicators: i) management of health and well-being tourism promotion products, ii) management of processes and quality of services or products, iii) human resource management and development, iv) financial and cost management, v) marketing management, vi) management to understand client needs, vii) crisis management, viii) maintaining health and well-being tourism resources, environmental sustainability and reducing the amount of waste in the organisation and ix) strategic management for health and well-being tourism.

7. Innovation capacity is comprised of six indicators: i) application of electronic tourism systems and other relevant service innovations, ii) human capital for new services, such as personnel with knowledge and expertise in health and well-being tourism, creativity and passion for developing new products or services, iii) open to service innovation, iv) bringing local resources, knowledge and unique local identity to create strength of sale and add value to health and wellbeing tourism products and services, v) continuous development of new work processes and vi) always prepared; proposes new options instead of using the same old methods to solve problems quickly.

As previously detailed, the seven components of health and well-being tourist destinations' competitiveness enhancement consist of 41 indicators. The samples indicate that the destination management, service design and development, innovation capacity, health and well-being tourism attraction and resources, policy, planning and destination development, knowledge management and learning organisations are the most critical factors affecting the development of the competitiveness of health and well-being tourism destinations. Additionally, the samples' perspectives on the components of the competitiveness advancement of health and well-being tourist destinations in all seven critical dimensions were compatible with the empirical data, with minimal variations and a similar direction.

\section{DISCUSSIONS AND RECOMMENDATIONS}

\section{Discussion}

The research revealed seven components of competitiveness development of health and well-being tourist destinations and that these components are compatible with the empirical evidence. Each component is discussed as follows.

1. Health and well-being tourism resources and attractions include distinctive and memorable identities and tourism activities that can provide learning experiences and lasting impressions and involve interactions with indigenous people, such as the production of wellness and herbal products for tourists. This finding is consistent with previous studies that demonstrated that the resource is distinct, diversified and specialised in health tourism (Mi et al., 2019; Pan et al., 2019). A key to success is the organisation of varied tourist events to improve health, entertain and educate visitors about the community's culture and way of life (Liu et al., 2019). Additionally, arranging events that give tourists a sense of community helps local communities earn more money (Reitsamer and Brunner-Sperdin, 2016). These key indications of success assist in developing health tourism resources and attractions.

2. Infrastructure and facilities include the transportation network that connects tourists' accommodation to their tourism destinations, infrastructure used to provide information to tourists, wellness promotion services and activities, such as yoga, exercise and aerobics and the design of tourist facilities that cater to various clientele. This conclusion is consistent with previous studies that demonstrated the availability of infrastructure and transportation coupled with a diverse range of trip destinations and ease of access (Gaman, 2015; Reitsamer and Brunner-Sperdin, 2016; Šajinović, 2017) and the arrangement of information centres for tourists (Roy et al., 2017; Dodescu and Cohut, 2016; Salinas Fernández et al., 2020; Portolan, 2019). Providing health promotion services in addition to traditional health and mental health care is also consistent with previous findings (Demir and Dundar, 2018; Gaman, 2015). Moreover, the design of beautiful and stable architectural structures that are capable of accommodating the needs of all types of tourists is consistent with other research (Gajić et al., 2018; Gaman, 2015; Li et al., 2016). These elements are all critical indicators of the structure and facilities required for the successful development of health tourism destinations.

3. Service design and development include delivering wellness services with knowledge and expertise, using natural methods to promote wellness, such as herbal baths, oil massage and hydrotherapy, creating a relaxing environment for clients to use wellness promotion services through such things as décor that is in harmony with nature and appropriate soothing music and designing service processes through tracking. These findings corroborate previous studies that demonstrated the importance of workers' competence and attention to service quality (Andrades and Dimanche, 2019; Gajić et al., 2018), healing and restoration using ancient wisdom and natural remedies (Kelly et al., 2015), creating a comfortable environment via dialogue and using edifying music to provide a calm atmosphere to visitors utilising the service (Erbaş and Perçin, 2015; Junio et al., 2016; Reitsamer and Brunner-Sperdin, 2016; Yan et al., 2017) and promptly responding to travellers' needs, concerns and demands (Chen et al., 2016; Naidoo et al., 2011). Previous studies also stressed the need to concentrate efforts on establishing personnel training programmes to improve service efficiency 
(Naidoo et al., 2011) and collaboration between health promotion professionals in various disciplines to provide visitors with high-quality rehabilitation and healing services (Kelly et al., 2015). Each factor is essential when designing and developing health tourism services.

4. Policy, planning and destination management includes a focus on consistent economic development that primarily contributes to the local community and environment, laws, policies and measures supported by government agencies, the ability to assess risks to tourists using services/visiting, concept presentation/delivering value to tourists, brand development, destination experience, wellness tourism and adherence to global standards that tourists recognise and accept. These findings are consistent with previous research that focused on building the economic system of the local community and enhancing its quality of life (Suphachaimongkol et al., 2019) and studies that looked at legislation, rules and policies supporting health tourism by government agencies (Roy et al., 2018). The capacity to evaluate tourists or service recipients (Andrades and Dimanche, 2019) delivers impressive and valuable wellness services (Erbaş and Perçin, 2015; Szromek and Naramski, 2019). Another key element of success is developing a brand image, personality and appeal consistent with the destination's identity (Armenski et al., 2018; Chen et al., 2016; Hanafiah and Zulkifly, 2019). Additionally, the wellness destination must be capable of accepting foreign tourists, conducting international business and adhering to internationally recognised standards for health tourism services (Añaña et al., 2018; Augustin and Liaw, 2017; Dodescu and Cohut, 2016; Demir and Dundar, 2018; Salinas Fernández et al., 2020; Junio et al., 2016; Portolan, 2019; Reisinger et al., 2019). All of these are key markers of health tourism destination policy, planning and development.

5. Knowledge management and learning organisations include knowledge transfer and consulting for business partners, assembling and storing knowledge to provide wellness tourism services to tourists, nursing homes, researchers or students and new entrepreneurs interested in starting a business, connecting and applying knowledge to create new knowledge or new services and possessing the necessary, basic knowledge for e-commerce businesses. These outcomes corroborate prior studies that indicate the importance of transferring knowledge and providing business advice to business partners (Suphachaimongkol et al., 2019), accumulating and disseminating information to the community and business partners to improve health tourism services that represent rehabilitative expertise and indigenous wisdom (Suphachaimongkol et al., 2019), and integrating and implementing health tourism knowledge to generate new information and innovative health tourism goods and services (Andrades and Dimanche, 2019; Armenski et al., 2018; Suphachaimongkol et al., 2019). Furthermore, this information supports prior research on the capacity to apply existing information or knowledge proficiently and effectively, including business operations through electronic commerce channels powered by IT systems, to gain a competitive edge and respond quickly to changes (Andrades and Dimanche, 2019; Armenski et al., 2018). A commitment to lifetime learning and skill development to sustain an organisational and learning culture was found to be critical (Armenski et al., 2018; Bilbao-Terol et al., 2017), as was learning alongside diverse groups of people, communities, cultures and experts in indigenous wisdom-based health restoration (Asmelash and Kumar, 2019; Kelly et al., 2015; Suphachaimongkol et al., 2019). In fact, all indicators are critical for health tourism destination knowledge management and a learning organisation.

6. Destination management encompasses the management of wellness promotion products, processes and the quality of services/products, finances and costs, client needs, market, the maintenance of wellness tourism resources/environmental sustainability and crises; the management and development of human resources and the reduction of waste. This result is consistent with previous studies that demonstrated that the creation and invention of diverse, exceptional and high-quality health tourism goods are vital (Andrades and Dimanche, 2019; Armenski et al., 2018; Mi et al., 2019) and that business process management with expertise and timely service quality management must satisfy tourists (Chen, 2020; Krstic et al., 2016). Other research that focused on human resource management and development (Andrades and Dimanche, 2019; Salinas Fernández et al., 2020; Hanafiah and Zulkifly, 2019; Krstic et al., 2016; Reisinger et al., 2019; Reitsamer and Brunner-Sperdin, 2016), Financial Resource Management (Añaña et al., 2018; Camisón et al., 2016; Hanafiah and Zulkifly, 2019; Liou et al., 2019; Suphachaimongkol et al., 2019) and Travel Destination Marketing Management (Camisón et al., 2016; Erbaş and Perçin, 2015; Hanafiah and Zulkifly, 2019; Semenova et al., 2018) are all congruent with this study's findings. The importance of recognising tourists' requirements (Andrades and Dimanche, 2019; Szromek and Naramski, 2019), crises management (Crouch, 2010) and planning and policy development for the management of environmentally sustainable tourism destinations (Armenski et al., 2018; Asmelash and Kumar, 2019; Augustin and Liaw, 2017; Dodescu and Cohut, 2016; Salinas Fernández et al., 2020; Horng et al., 2018; Kelly et al., 2015; Krstic et al., 2016; Portolan, 2019; Reisinger et al., 2019; Romão et al., 2017) are oother results that are consistent with this research. Additionally, strategic management for health tourism is required (Liou et al., 2019; Suphachaimongkol et al., 2019). These markers are critical to the management of tourism destinations.

7. Innovative capacity includes the use of electronic tourism systems, other pertinent service innovations and human capital for new services, such as individuals with knowledge and skills in wellness tourism and creativity and enthusiasm for producing new goods or services. Openness to service innovation, bringing local resources, knowledge and a distinct local identity to strengthen sales and add value to tourism products and services, continuous development of new work processes and always being prepared to propose new solutions rather than relying on tried-and-true methods to resolve problems quickly are all critical elements of success. These findings corroborate prior studies that discovered that technological readiness is a critical instrument for driving business and developing service improvements (Bilbao-Terol et al., 2017; Horng et al., 2018; Krstic et al., 2016; Demir and Dundar, 2018), along with human resource preparedness for new service development (Reisinger et al., 2019; Romão et al., 2017; Roy et al., 2018). Navigating geographic indicators of natural and cultural resources in indigenous communities to identify sales points and develop them into new products 
(Armenski et al., 2018; Kurek et al., 2020; Reitsamer and Brunner-Sperdin, 2016; Roy et al., 2018), gaining exposure to service innovation and the ability for knowledge absorption (Dodescu and Cohut, 2016; Hanafiah and Zulkifly, 2019; Romão et al., 2017) and improving work techniques to provide continuity of health promotion services involving collaboration with appropriate interdisciplinary specialists (Armenski et al., 2018; Kelly et al., 2015) are other important findings that are congruent with this study. Moreover, critical indicators of innovative capacity include constantly preparing for and discovering new ways to deliver services that differentiate themselves from competitors and increase efficiency in the development of new health tourism services that add value to tourists (Liou et al., 2019; Šajinović, 2017).

\section{Application of the Present Findings}

This study identifies the essential components and indicators for research results to be developed and the information to increase the competitiveness of tourist health and well-being destinations. This study also provides detailed information on these components and indicators. Finally, recommendations for government agencies, health and well-being tourism institutions in Thailand and operators of health and well-being destinations, communities, societies and public transport services are provided. Clearly, many diverse and important factors need to be considered to develop a globally competitive tourism destination for holistic health and well-being. These factors include the effective application to similar health and well-being tourism resource and attraction projects infrastructure, design and development of services, policies, planning and management of destinations, knowledge management and learning organisations, destination management and innovative capacity. Furthermore, the generated indicators can be used to develop decision support schemes as administrative tools and for comparisons and formulations of strategies to improve the competitiveness of health and well-being tourist destinations, giving cluster operators, the public and private sectors and stakeholders a sustainable competitive advantage.

\section{Future Research}

This research develops a conceptual framework based on a systematic review of the most relevant past research literature from foreign countries. Therefore, in-depth information on developing the competitiveness of health and wellness tourism destinations suitable for the Thai context might be lacking. Therefore, researchers can extend this research in subsequent studies by undertaking mixed-method research involving both qualitative and quantitative analyses to expand and increase the depth of the data through in-depth interviews, focus groups and other appropriate methods.

\section{REFERENCES}

Aaker, D.A., Kumar, V., \& Day, G.S. (2000). Marketing Research. (7 ${ }^{\text {th }}$ ed.). New York: John Wiley \& Sons, Inc.

Akarawong, S. T., Kingkaew, R., Sangduen, N., Jinpon, P., \& Julatha, W. (2020). Development of Nakhon Si Thammarat as a Center of Health Tourism in the Upper South of Thailand. Journal of Southern Technology, 13(1), 191-199, (in Thai). https://so04.tcithaijo.org/ index.php/journal_sct/article/view/194969

Aksornpairoj, P. (2020). The Guidelines for Developing Competitive Advantage of Wellness Tourism Business in Phuket. Journal of Management Science Chiangrai Rajabhat University, 15(1), 1-25. (in Thai). https://so03.tci-thaijo.org/index.php/jmscrru/article/view/130325

Añaña, E.D.S., Rodrigues, R.C., \& Flores, L.C.D.S. (2018). Competitive performance as a substitute for competiveness measurement in tourism destinations: an integrative study. International Journal of Tourism Cities, 4(2), 207-219. https://doi.org/10.1108/ijtc-07-2017-0035

Andrades, L., \& Dimanche, F. (2019). Destination competitiveness in Russia: tourism professionals' skills and competences. International Journal of Contemporary Hospitality Management, 31(2), 910-930. https://doi.org/10.1108/ijchm-11-2017-0769

Armenski, T., Dwyer, L., \& Pavluković, V. (2017). Destination Competitiveness: Public and Private Sector Tourism Management in Serbia. Journal of Travel Research, 57(3), 384-398. https://doi.org/10.1177/0047287517692445

Armstrong, J.S., \& Overton, T.S. (1977). Estimating Nonresponse Bias in Mail Surveys. Journal of Marketing Research, 14, $396-402$. https://doi.org/10.2307/3150783

Asmelash, A.G., \& Kumar, S. (2019). Assessing progress of tourism sustainability: Developing and validating sustainability indicators. Tourism Management, 71, 67-83. https://doi.org/10.1016/j.tourman.2018.09.020

Augustin, J.L.P.M., \& Liaw, S.Y. (2017). Tourism competitiveness index of the Asia-Pacific region through consistency analysis. Asia Pacific Journal of Tourism Research, 22(12), 1295-1307. https://doi.org/10.1080/10941665.2017.1391855

Baruch, Y., \& Holtom, B.C. (2008). Survey response rate levels and trends in organizational research. Human Relations, 61(8), 11391160. https://doi.org/10.1177/0018726708094863

Bilbao-Terol, A., Arenas-Parra, M., \& Onopko-Onopko, V. (2017). Measuring regional sustainable competitiveness: a multi-criteria approach. Operational Research, 19(3), 637-660. https://doi.org/10.1007/s12351-017-0367-9

Byrne, B.M. (2001). Structural equation modeling with AMOS: basic concepts, applications, and programming. Mahwah, New Jersey: Lawrence Erlbaum Associated.

Camisón, C., Puig-Denia, A., Forés, B., Fabra, M.E., Muñoz, A., \& Muñoz Martínez, C. (2016). The Importance of Internal Resources and Capabilities and Destination Resources to Explain Firm Competitive Position in the Spanish Tourism Industry. International Journal of Tourism Research, 18(4), 341-356. https://doi.org/10.1002/jtr.2053

Chambers, D., \& McIntosh, B. (2008). Using Authenticity to Achieve Competitive Advantage in Medical Tourism in the Englishspeaking Caribbean. Third World Quarterly, 29(5), 919-937. https://doi.org/10.1080/01436590802106056

Chen, C.M., Chen, S.H., Lee, H.T., \& Tsai, T.H. (2016). Exploring destination resources and competitiveness-A comparative analysis of tourists' perceptions and satisfaction toward an island of Taiwan. Ocean \& Coastal Management, 119, 58-67. https://doi.org/ 10.1016/j.ocecoaman.2015.09.013

Chen, H. (2020). Complementing conventional environmental impact assessments of tourism with ecosystem service valuation: A case study of the Wulingyuan Scenic Area. China. Ecosystem Services, 43. https://doi.org/10.1016/j.ecoser.2020.101100

Chen, K.W., Ouyang, Y., Y.C., \& Huang, L.,T.L. (2016). The Study on the Service Quality and Satisfaction of Public Hot Spring Hotels. International Journal of Organizational Innovation, 9(1), 187-199. https://search.ebscohost.com/login.aspx?direct=true\&db $=$ bth $\& A N=116828297 \&$ site $=$ eds-live 
Chua, B.L., Al-Ansi, A., Lee, M.J., \& Han, H. (2020). Impact of health risk perception on avoidance of international travel in the wake of a pandemic. Current Issues in Tourism, 24(7), 985-1002. https://doi.org/10.1080/13683500.2020.1829570

Crouch, G.I. (2010). Destination Competitiveness: An Analysis of Determinant Attributes. Journal of Travel Research, 50(1), $27-45$. https://doi.org/10.1177/0047287510362776

Demir Uslu, Y., \& Dundar Ege, S. (2018). An Assessment of Competitive Factors in Medical Tourism. International Journal of Research in Business and Social Science (2147-4478), 7(2), 14-21. https://doi.org/10.20525/ijrbs.v7i2.876

Dodescu, A.O., Cohuţ, I., \& Pop, C. (2016). Competitiveness In The Tourism Sector. The Case of Romania. Annals of Faculty of Economics, University of Oradea, Faculty of Economics, 1(2), 182-193.

Erbaş, E., \& Perçin, N.Ş. (2015). Competitive Importance Performance Analysis (CIPA): An Illustration from Thermal Tourism Destinations. Business and Economics Research Journal, 6(4), 137-154.

Eze, F.J., Inyang, J.J., \& Orji, N.V. (2020). Determinants of Outbound Medical Tourism: Implications for Service Marketing and Development. GeoJournal of Tourism and Geosites, 33(4), 1507-1512. https://doi.org/10.30892/gtg.334spl09-600

Gajić, T., Penić, M., Vujko, A., \& Petrović, M.D. (2018). Development Perspectives of Rural Tourism Policy - a Comparative Study of Rural Tourism Competitiveness Based on Perceptions of Tourism Workers in Slovenia and Serbia. Eastern European Countryside, 24(1), 143-154. https://doi.org/10.2478/eec-2018-0007

Gaman, G. (2015). A Model of Assessing the Value of the Tourism Potential of Moinești, Târgu Ocna And Slănic Moldova Resorts (Romania). Geographica Timisiensis, 24(1), 1-15.

Ganguli, S., \& Ebrahim, A.H. (2017). A qualitative analysis of Singapore's medical tourism competitiveness. Tourism Management Perspectives, 21, 74-84. https://doi.org/10.1016/j.tmp.2016.12.002

Garau, C., \& Pavan, V. (2018). Evaluating Urban Quality: Indicators and Assessment Tools for Smart Sustainable Cities. Sustainability, 10(3), 575. https://doi.org/10.3390/su10030575

Goodrich, J.N., \& Goodrich, G.E. (1987). Health-care tourism - an exploratory study. Tourism Management, 8, $217-222$.

Gursoy, D., \& Chi, C.G. (2020). Effects of COVID-19 pandemic on hospitality industry: review of the current situations and a research agenda. Journal of Hospitality Marketing \& Management, 29(5), 527-529. https://doi.org/10.1080/19368623.2020.1788231

Hair, J.F., Black, W.C., Babin, B.J., Anderson, R.E., \& Tatham, R.L. (2006). Multivariate Data Analysis. $\left(6^{\text {th }}\right.$ ed.): Prentice Hall.

Hair, J.F., Black, W.C., Babin, B.J., \& Anderson, R.E. (2010). Multivariate Data Analysis. Upper Saddle River, New Jersey: Prentice Hall.

Hanafiah, M.H., \& Zulkifly, M.I. (2019). Tourism destination competitiveness and tourism performance. Competitiveness Review: An International Business Journal, 29(5), 592-621. https://doi.org/10.1108/cr-07-2018-0045

Harris, R.J. (2001). A primer of multivariate statistics. ( $3^{\text {rd }} \mathrm{ed}$.). Mahwah, NJ: Erlbaum.

Mosammam, H. M., Sarrafi, M., \& Nia, J. T. (2019). Measuring the competitiveness of Iran's health tourism. International Journal of Tourism Policy, 9(3), 201-221. https://doi.org/10.1504/IJTP.2019.104875

Helmy, E.M., \& Travers, R. (2009). Towards the Development of Egyptian Medical Tourism Sector. Anatolia, 20(2), 419-439. https://doi.org/10.1080/13032917.2009.10518918

Hongsub, A., \& Pookaiyaudom, G. (2015). The guidelines for developing hot spring resource in health tourism destination management in northern Thailand. Journal of Sports Science and Health, 16(3), 76-90 (in Thai).

Horng, J.S., Liu, C.H.S., Chou, S.F., Tsai, C.Y., \& Hu, D.C. (2018). Developing a sustainable service innovation framework for the hospitality industry. International Journal of Contemporary Hospitality Management, 30(1), 455-474. https://doi.org/10.1108/ijchm-12-2015-0727

Hu, L.T., \& Bentler, P.M. (1999). Cutoff criteria for fit indexes in covariance structure analysis: Conventional criteria versus new alternatives. Structural Equation Modeling: A Multidisciplinary Journal, 6(1), 1-55. https://doi.org/10.1080/10705519909540118

Julatha, W. (2019). Development of Health Tourism Destination of Nakhon Si Thammarat. Journal of Southern Technology, 12(2), 1-13. (in Thai). https://so04.tci-thaijo.org/index.php/journal_sct/article/view/185106

Junio, M.M.V., Kim, J.H., \& Lee, T.J. (2016). Competitiveness attributes of a medical tourism destination: The case of South Korea with importance-performance analysis. Journal of Travel \& Tourism Marketing, 34(4), 444-460. https://doi.org/10.1080/10548408.2016.1182454

Kelly, K., McCarthy, A., \& McLean, L. (2015). Distributed learning or medical tourism? A Canadian residency program's experience in global health. Journal of Surgical Education, 72(4), e33-45. https://doi.org/10.1016/j.jsurg.2015.01.004

Krstic, B., Jovanovic, S., Jankovic-Milic, V., \& Stanisic, T. (2016). Examination of travel and tourism competitiveness contribution to national economy competitiveness of sub-Saharan Africa countries. Development Southern Africa, 33(4), 470-485. https://doi.org/10.1080/0376835x.2016.1179103

Kurek, K.A., Heijman, W., van Ophem, J., Gędek, S., \& Strojny, J. (2020). The impact of geothermal resources on the competitiveness of municipalities: evidence from Poland. Renewable Energy, 151, 1230-1239. https://doi.org/10.1016/j.renene.2019.11.126

Lee, C.W., \& Li, C. (2019). The Process of Constructing a Health Tourism Destination Index. International Journal of Environmental Research and Public Health, 16(22). https://doi.org/10.3390/ijerph16224579

Li, J., Kim, W.G., \& Wong, I.A. (2016). Does destination perception differ based on traveler type? A case of the world gambling capital: Macau. Tourism Planning \& Development, 14(1), 15-30. https://doi.org/10.1080/21568316.2016.1152289

Liou, J. J. H., Kaklauskas, A., Lu, M.-T., \& Chuang, Y.-C. (2019). Improving strategic orientations for promoting hotel services using an integrated rough MAGDM model. Technological and Economic Development of Economy, 25(2), 188-218. https://doi.org/10.3846/tede.2019.8419

Liu, X., Fu, Y., Chao, R.F., \& Li, J. (2016). A formative measurement approach for exploring how to form service quality in hot spring resorts. Tourism and Hospitality Research, 19(1), 27-39. https://doi.org/10.1177/1467358416683767

Lo, M.C., Chin, C.H., \& Law, F.Y. (2017). Tourists' perspectives on hard and soft services toward rural tourism destination competitiveness: Community support as a moderator. Tourism and Hospitality Research, 19(2), 139-157. https://doi.org/10.1177/1467358417715677

Loo, R., \& Thorpe, K. (2000). Confirmatory factor analyses of the full and short versions of the Marlowe-Crowne Social Desirability Scale. The Journal of Social Psychology, 140(5), 628-635. https://doi.org/10.1080/00224540009600503

Meyers, L.S., Gamst, G., \& Guarino, A.J. (2013). Applied multivariate research: Design and interpretation. (2nd ed.). Sage Publications, Inc.

Medina-Muñoz, D.R., \& Medina-Muñoz, R.D. (2014). The Attractiveness of Wellness Destinations: An Importance-PerformanceSatisfaction Approach. International Journal of Tourism Research, 16(6), 521-533. https://doi.org/10.1002/jtr.1944

Meera, S., \& Vinodan, A. (2019). Attitude towards alternative medicinal practices in wellness tourism market. Journal of Hospitality and Tourism Insights, 2(3), 278-295. https://doi.org/10.1108/jhti-06-2018-0037

Mi, C., Chen, Y., Cheng, C.S., Uwanyirigira, J.L., \& Lin, C.T. (2019). Exploring the Determinants of Hot Spring Tourism Customer Satisfaction: Causal Relationships Analysis Using ISM. Sustainability, 11(9). https://doi.org/10.3390/su11092613 
Mueller, H., \& Kaufmann, E.L. (2001). Wellness tourism: Market analysis of a special health tourism segment and implications for the hotel industry. Journal of Vacation Marketing, 7(1), 5-17. https://doi.org/10.1177/135676670100700101

Naidoo, P., Ramseook-Munhurrun., \& Prabha, S., Premita. (2011). An Assessment of Visitor Satisfaction with Nature-Based Tourism Attractions. International Journal of Management and Marketing Research, 4(1), 87-98. https://ssrn.com/abstract=1881032

Novikova, N. G., Sakharchuk, E. S., \& Ilkevich, S. V. (2013). The factors of Russia's low competitiveness as a medical tourism destination. World Applied Sciences Journal, 27, 251-255. https://doi.org/10.5829/idosi.wasj.2013.27.elelc.52

Pan, Y., \& Han, L., Liu. (2019). Evaluating Potential Areas for Mountain Wellness Tourism: A Case Study of Ili, Xinjiang Province. Sustainability, 11(20), 5668. https://doi.org/10.3390/su11205668

Portolan, A. (2019). The Competitiveness of the Republic of Croatia on the European Union Tourism Market. ToSEE - Tourism in Southern and Eastern Europe, 5, 581-595. https://doi.org/10.20867/tosee.05.15

Rattanadilok na Phuket, K., \& Weerakit, N. (2019). An Evaluation of The Readiness of Hot Spring, Amphoe Khlong Thom, Changwat Krabi To Be Developed as A Prototype of Hot Spring-Health Tourism. Veridian E-Journal,Silpakorn University, 12(3), 1031-1051 (in Thai).

Reisinger, Y., Michael, N., \& Hayes, J.P. (2019). Destination competitiveness from a tourist perspective: A case of the United Arab Emirates. International Journal of Tourism Research, 21(2), 259-279. https://doi.org/10.1002/jtr.2259

Reitsamer, B.F., \& Brunner-Sperdin, A. (2016). Tourist destination perception and well-being. Journal of Vacation Marketing, 23(1), 5572. https://doi.org/10.1177/1356766715615914

Romão, J., Machino, K., \& Nijkamp, P. (2017). Assessment of wellness tourism development in Hokkaido: a multicriteria and strategic choice analysis. Asia-Pacific Journal of Regional Science, 1(1), 265-290. https://doi.org/10.1007/s41685-017-0042-4

Rovinelli, R.J., \& Hambleton, R.K. (1977). On the use of content specialists in the assessment of criterion-referenced test item validity. Dutch Journal of Educational Research, 2, 49-60.

Roy, J., Chatterjee, K., Bandyopadhyay, A., \& Kar, S. (2018). Evaluation and selection of medical tourism sites: A rough analytic hierarchy process based multi-attributive border approximation area comparison approach. Expert Systems, 35(1). https://doi.org/10.1111/exsy.12232

Šajinović, S. (2017). Tourist Destination Branding in Function of Market Positioning and Increased Competitiveness of Spa Tourism. Зборник Радова Економског Факултета У Источном Сарајеву, 1(13). https://doi.org/10.7251/zrefis1613029s

Salinas Fernández, J.A., Serdeira Azevedo, P., Martín Martín, J.M., \& Rodríguez Martín, J.A. (2020). Determinants of tourism destination competitiveness in the countries most visited by international tourists: Proposal of a synthetic index. Tourism Management Perspectives, 33, 100582. https://doi.org/10.1016/j.tmp.2019.100582

Schalber, C., \& Peters, M. (2012). Determinants of health tourism competitiveness: an alpine case study. Tourism: An international Interdisciplinary Journal, 60, 307-323.

Semenova, L.V., Zaitseva, N.A., Larionova, A.A., Senyugina, Irina A., Ivanova, E.V., \& Polozhentseva, I. V. (2018). Development of a system of quantitative and qualitative indicators for assessing the competitiveness of the hospitality industry. Espacios, 39(22), 1-13.

Sheldon, P.J., \& Bushell, R. (2009). Introduction to wellness and tourism. Wellness and Tourism: Mind, Body, Spirit, Place

Snezana Milicevic, Vesna Milovanovic, \& Mandaric, M. (2013). Potentials of Serbia as Medical Tourism Destination at the International Tourism Market. [Актуальні Проблеми Економіки], 4(142), 397-404.

Suphachaimongkol, C., Ratanatamskul, C., Silapacharanan, S., \& Utiswannakul, P. (2019). Development of Mobile Application for Sustainable Creative Tourism Assessment using Confirmatory Factor Analysis Approach. International Journal of Interactive Mobile Technologies (iJIM), 13(6), 27-40. https://doi.org/10.3991/ijim.v13i06.10500

Szromek, A.R., \& Naramski, M. (2019). A Business Model in Spa Tourism Enterprises: Case Study from Poland. Sustainability, 11(10), 2880. https://doi.org/10.3390/su11102880

Tapak, L., Abbasi, H., \& Mirhashemi, H. (2019). Assessment of factors affecting tourism satisfaction using K-nearest neighborhood and random forest models. BMC Research Notes, 12(1), 749. https://doi.org/10.1186/s13104-019-4799-6

Težak, D.A. (2019). Wellness and healthy lifestyle in tourism settings. Tourism Review, 74(4), 978-989. https://doi.org/10.1108/tr-022019-0046

Wang, J., Huang, X., Gong, Z., \& Cao, K. (2020). Dynamic assessment of tourism carrying capacity and its Impacts on tourism economic growth in urban tourism destinations in China. Journal of Destination Marketing \& Management, 15, 100383. https://doi. org/10.1016/j.jdmm.2019.100383

Yan, L., Gao, B.W., \& Zhang, M. (2017). A mathematical model for tourism potential assessment. Tourism Management, 63, 355-365. https://doi.org/10.1016/j.tourman.2017.07.003

*** Department of Health Service Support, Ministry of Public Health. (2016). Thailand Strategy provide health promotion (Medical Center) (2017-2026). Retrieved from https://hss.moph.go.th/fileupload/2560-102.pdf

*** Medical Tourism Association. (2020). Medical Tourism Index 2020-2021. https://www.medicaltourism.com/destinations/thailand

*** National News Bureau of Thailand. (2020). Health Minister eyes Thailand's medical tourism post COVID-19. https://thainews. prd.go.th/en/news/detail/TCATG201119160931829

*** Soper, D.S. (2020). A-priori Sample Size Calculator for Structural Equation Models. https://www.danielsoper.com/statcalc

*** UNWTO. (2021). 2020: Worst Year in Tourism History With 1 Billion Fewer International Arrivals. https://www.unwto. org/news/2020-worst-year-in-tourism-history-with-1-billion-fewer-international-arrivals

Article history: Received: 30.07.2021 Revised: 28.11.2021 Accepted: 16.12.2021 Available online: 31.12 .2021 